\title{
Electrochemical Comparative Study of Riboflavin, FMN and FAD Immobilized on the Silica Gel Modified with Zirconium Oxide
}

\author{
Miyuki Yamashita, Simone S. Rosatto and Lauro T. Kubota* \\ Instituto de Química, Universidade Estadual de Campinas, CP 6154, 13083-970 Campinas - SP, Brazil
}

\begin{abstract}
Eletrodos de pasta de carbono modificados foram preparados pela inclusão de flavinas adsorvidas sobre a sílica gel modificada com óxido de zircônio (Si:Zr:flavina). O comportamento eletroquímico de riboflavina, FMN e FAD imobilizadas foi investigado. O potencial formal, $E^{\mathrm{o}^{\prime}}$, para as flavinas neste eletrodo foi encontrado como sendo $-0,46 \mathrm{~V} v$ s. SCE, que é comparável com os valores obtidos para estas espécies em solução. Além disso, os valores de $E^{0^{\prime}}$ permaneceram dependentes do $\mathrm{pH}$ com certa independência para riboflavina entre $\mathrm{pH} 4$ e 5 . A composição do eletrólito de suporte não afetou o $E^{\circ}$ com exceção de $\mathrm{Ca}^{2+}$, mas em sistemas tampões e especialmente em fosfato foram verificadas velocidades satisfatórias de transferência de elétrons. As diferenças observadas no comportamento eletroquímico e espectro de absorção UV-visível entre as flavinas imobilizadas foram discutidas em termos de diferentes tipos de interação.
\end{abstract}

Modified carbon paste electrodes were prepared by the adsorption of flavin on a silica gel modified with zirconium oxide (Si:Zr:flavin). The electrochemical behavior of immobilized riboflavin, FMN and FAD was investigated. The formal potentials, $E^{0^{\prime}}$, for the flavins in these electrodes were found to be $-0.46 \mathrm{~V} v s$. SCE, this being similar to their values obtained in solution. Their $E^{\mathrm{o}^{\prime}}$ values remained $\mathrm{pH}$ dependent with certain invariance for riboflavin between 4 and 5 . The composition of the supporting electrolyte did not affect the $E^{\circ-}$ with exception of $\mathrm{Ca}^{2+}$, but in buffer systems and especially in phosphate a good rate of electron transfer was observed. The differences verified in the electrochemical behavior and UV-visible absorption spectra among the immobilized flavins are discussed in terms of different kinds of interaction.

Keywords: flavin, carbon paste electrode, silica gel, zirconium oxide

\section{Introduction}

Flavins work as co-factors and form an integral part of the redox active sites of many different enzymes involved in dehydrogenation reactions, dioxygen activation, and electron transfer reactions. ${ }^{1,2}$ The understanding of the versatile chemistry of flavins and the mechanisms of action of flavoprotein enzymes is of extreme importance and has been focus of many investigations. ${ }^{3-5}$

The riboflavin (RF), vitamin $\mathrm{B}_{2}$, is an essential precursor of flavin adenine dinucleotide (FAD) and flavin mononucleotide (FMN) co-enzymes. Another compound of the flavin family is lumiflavin. ${ }^{6}$ The flavins have in common the isoalloxazine ring system where the redox process occurs, Figure 1b. The nature of the group attached to the N-10, Figure 1a, is the flavin members differentiation

\footnotetext{
* e-mail: kubota@iqm.unicamp.br
}

and can influence the flavin adsorption orientation on the electrode surface, ${ }^{7,8}$ leaving the active site more or less available. The redox process of the flavins is thermodynamically reversible, irrespective of whether one or two electrons per flavin molecule are being transferred, which means that their redox states (quinone state, semiquinone state, hydroquinone state) must be considered..$^{6,9}$

The importance of flavins in enzymatic catalysis motivates the studies of the electrochemical behavior of monolayers or aggregates containing synthetic flavins. ${ }^{10}$ Another special interest in flavins is the study of their reaction with dihydronicotinamide adenine dinucleotide (NADH). ${ }^{7,11,12}$ Many electrochemical investigations have been made with the goal of elucidating the mechanism of this reaction. However a major obstacle found in that kind of study is the relative low difference between the $E^{\circ}$ values of NADH and of free flavin which results in a slow kinetics of this redox reaction. Attempts to increase the reaction 


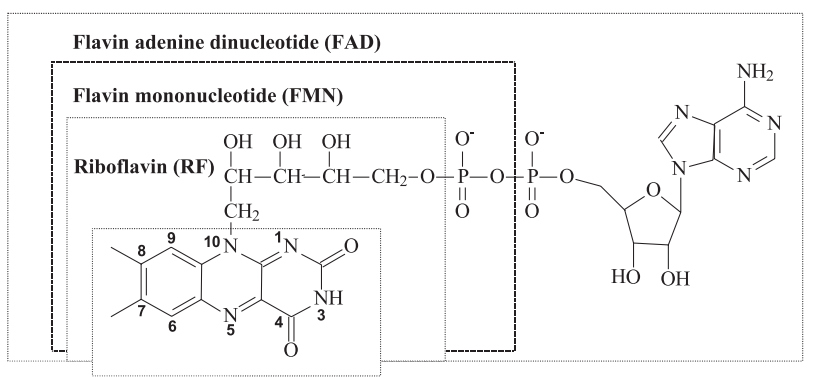

b

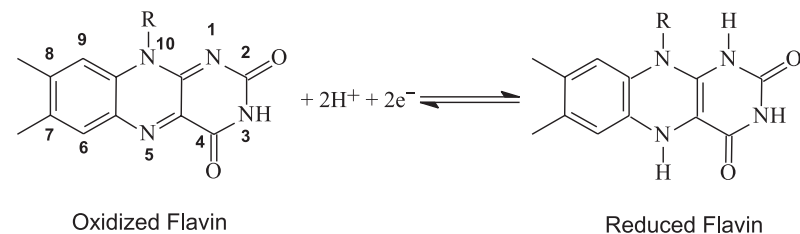

Figure 1. Chemical structures and nomenclature of the flavins in the oxidized state (a) and redox process of part (alloxazin ring) of the flavin structure (b)

rate between flavins and $\mathrm{NADH}$ include derivating flavins, ${ }^{13-15}$ immobilization of flavins on matrices to cause a shift of its $E^{0^{\prime}}$ toward more positive values. ${ }^{16-18}$ Flavins have been adsorbed on graphite, glassy carbon, platinum and gold ${ }^{19}$ electrodes surfaces and have also been attached through mercaptan ${ }^{20}$ and thiourea ${ }^{21}$ linkages to noble metal substrates or using of the Langmuir-Blodgett technique. ${ }^{22}$ However, many systems show slow electron transfer rates, weak flavin-conductor interaction or suffer from instability due to flavin desorption. ${ }^{21}$

Surface or bulk modified carbon paste electrodes are useful configurations to incorporate electroactive species for analytical purposes. The immobilization of riboflavin on zirconium phosphate (ZP) or titanium phosphate (TP) in carbon paste yielded an $E^{\mathrm{o}^{\prime}}$ shift of approximately 250 $\mathrm{mV}$ or $100 \mathrm{mV}$, respectively, towards a more positive potential compared with their values in solution. ${ }^{17,18}$ This shift was assigned to the interaction between the basic nitrogen of riboflavin and the acid groups of ZP or TP. In addition $E^{\mathrm{o}^{\prime}}$ was independent of the solution $\mathrm{pH}$, which was attributed to the protection effect of ZP over riboflavin. However, under the same conditions, FAD and FMN did not adsorb on $\mathrm{ZP}^{16}$ or $\mathrm{TP},{ }^{18}$ but were strongly adsorbed on titanium oxide dispersed on carbon fibers.

Immobilized flavins show an $E^{\mathrm{o}^{\prime}}$ shifted approximately $200 \mathrm{mV}$ toward more positive values and are less dependent on the solution $\mathrm{pH}$ in comparison to dissolved flavins. ${ }^{23}$

Materials based on silica have been used to immobilize organic dyes in carbon paste electrodes and have been shown to improve the electrochemical activity and/or to shift their potential to a more desirable potential range. ${ }^{24-26}$ Silica gel presents attractive properties such as high capacity of adsorption, high specific surface area, porosities and good thermal and chemical stability that facilitates a varied modification of its surface with different functional groups.

In these studies the modified carbon paste electrodes were prepared by inclusion of flavin adsorbed on silica gel modified with zirconium oxide (Si:Zr:flavin). RF, FMN and FAD were investigated for their ability to bind to $\mathrm{Si}: \mathrm{Zr}$ and their electrochemical activity in the immobilized state. The results are discussed in terms of the interaction between the flavin and the Si:Zr matrix.

\section{Experimental}

\section{Zirconium (IV) oxide coating on silica gel (Si:Zr)}

Silica gel (Merck/German) with a specific surface area, $\mathrm{S}_{\mathrm{BET}}$, of $460-520 \mathrm{~m}^{2} \mathrm{~g}^{-1}$ and particle size between 0.040 $0.063 \mathrm{~mm}$, was dried at $373 \mathrm{~K}$ for $6 \mathrm{~h}$. The activated silica gel, $50 \mathrm{~g}$, was added to a solution containing $16.3 \mathrm{~g}(0.05$ mol L'-1) of zirconium (IV), $\mathrm{ZrOCl}_{2} \cdot 6 \mathrm{H}_{2} \mathrm{O}$ (Vetec), dissolved in $300 \mathrm{~mL}$ of water. The mixture was refluxed for $6 \mathrm{~h}$, and the resulting solid was washed by decantation, filtered and then heated at $373 \mathrm{~K}$ for drying.

\section{Adsorption of flavin on the Si:Zr surface}

About $400 \mathrm{mg}$ of matrix $\mathrm{Si}: \mathrm{Zr}$ was immersed in $10 \mathrm{~mL}$ of $1 \mathrm{mmol} \mathrm{L}^{-1}$ flavin mononucleotide (FMN-Sigma) or flavin adenine dinucleotide (FAD-Sigma) solutions, and the mixture was shaken for $90 \mathrm{~min}$. For studies on the adsorption of riboflavin (RF-Sigma), the same quantity of matrix Si:Zr was used for $20 \mathrm{~mL}$ of $0.5 \mathrm{mmol} \mathrm{L}^{-1} \mathrm{RF}$ solution and shaken for $3 \mathrm{~h}$ at room temperature.

\section{Characterization of Si:Zr and Si:Zr:flavin}

The quantity of zirconium was determined by X-ray fluorescence using a Spectrace 5000 spectrometer. The specific surface area, $\mathrm{S}_{\mathrm{BET}}$, was determined by the BET multipoint technique using a Micromeritcs Flow Sorb II 2300 apparatus. The quantity of RF, FAD and FMN immobilized on modified silica gel surface was obtained by elementally analysis, using a PE 2400 equipment.

The UV-visible absorption spectra of Si:Zr:RF, Si:Zr:FMN and Si:Zr:FAD were obtained by suspending the solids in liquid mineral oil using a quartz cell with 1 $\mathrm{mm}$ path length. These measurements were carried out using a Beckman DU-640 spectrophotometer. The spectra 
of the Si:Zr:flavins were compared to those obtained with flavins dissolved in aqueous solution.

\section{Preparation of carbon paste electrode}

The carbon paste was prepared using $56 \%$ of Si:Zr:flavin (Si:Zr:FAD or Si:Zr:FMN or Si:Zr:RF) and $44 \%$ of the graphite powder and mixed vigorously dropping mineral oil ( $80 \mu \mathrm{L}$ per $100 \mathrm{mg}$ of total mass) until obtaining a homogeneous paste. This paste was put into a cavity in contact with a platinum disk fused at the end of a glass tube with $3 \mathrm{~mm}$ internal diameter and pressed to smooth the surface.

\section{Electrochemical measurements}

Cyclic voltammetry (CV) experiments were carried out using a conventional cell with three-electrode compartment at room temperature. Nitrogen was passed through the solutions for at least $20 \mathrm{~min}$ before the measurements. A platinum foil $(0.8 \mathrm{~cm} \times 1.4 \mathrm{~cm})$ as auxiliary, a saturated calomel (SCE) as reference and the modified carbon paste electrode as working were used to perform the voltammetric measurements.

All electrochemical experiments were carried out with a potentiostat, PGSTAT 30, from Autolab (Eco Chemie, Utrecht, The Netherlands) coupled to a PC microcomputer for potential control and data acquisition.

\section{Results and Discussion}

\section{Characterization of the materials}

The amount of $1.2 \pm 0.1 \mathrm{mmol} \mathrm{g}^{-1}(10.5 \mathrm{wt} \%)$ of zirconium oxide was grafted onto the silica gel surface, as determined by X-ray fluorescence. Its specific surface area was $426 \pm 20 \mathrm{~m}^{2} \mathrm{~g}^{-1}$, as determined by the BET method.

The adsorption of zirconium onto a silica gel surface can be described by: $:^{27}$

$$
2 \mathrm{SiOH}+\mathrm{ZrOCl}_{2}+\mathrm{H}_{2} \mathrm{O} \rightarrow(\mathrm{SiO})_{2} \mathrm{Zr}(\mathrm{OH})_{2}+2 \mathrm{HCl}
$$

The material Si:Zr was used to immobilize the flavins. Under the same experimental conditions, the adsorption of FAD and FMN resulted in a material showing an intense yellow color, while in the presence of RF the resulting material was yellow clearer. This color is characteristic of the flavins, indicating its adsorption on to $\mathrm{Si}: \mathrm{Zr}$. The quantity of flavins adsorbed on Si:Zr was $19 \pm 4,33 \pm 9$ and $28 \pm 5 \mu \mathrm{mol} \mathrm{g}^{-1}$ for RF, FMN and FAD, respectively. The higher amount of adsorbed FMN and FAD can be attributed to the large affinity of zirconium to the phosphate group present in flavin structure. ${ }^{28} \mathrm{~A}$ similar stronger adhesion of FAD and FMN, in comparison to $\mathrm{RF}$, at $\mathrm{TiO}_{2}$ surface was reported. ${ }^{29}$ However, other types of interaction must also be involved, since RF, which does not have a phosphate group, was also adsorbed on $\mathrm{Si}: \mathrm{Zr}$.

UV-visible spectra of free and adsorbed flavins were recorded in order to provide more information about the interaction between flavins and the matrix. A conventional flavin is known to have two characteristic absorption bands at ca. 370 and $444 \mathrm{~nm}$ for the oxidized form, in the visible range. ${ }^{30}$ Comparing the spectra of the adsorbed flavins on Si:Zr (Figure 2a and 3a) with those for flavins in solution (Figure $2 b$ and Figure 3b), spectral changes for adsorbed

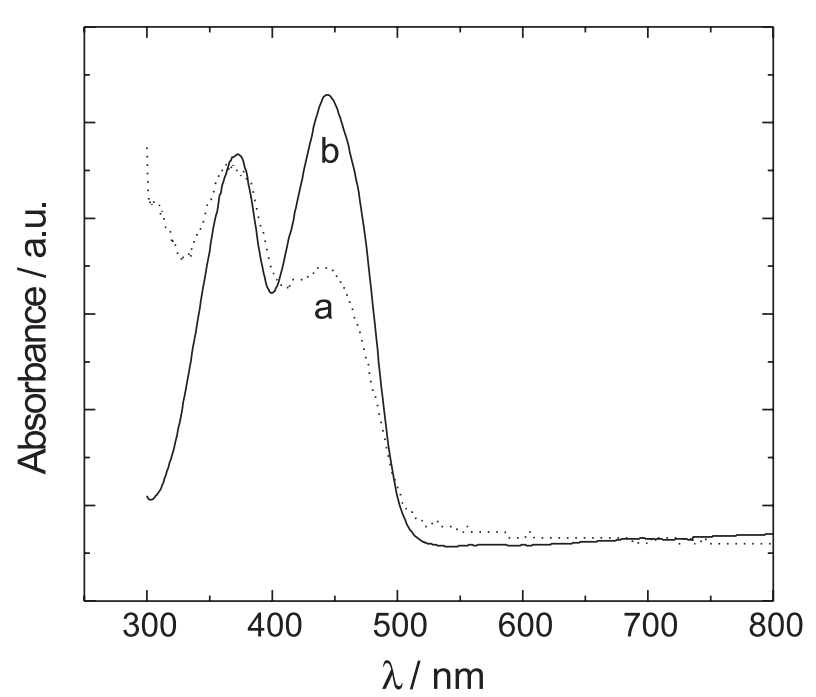

Figure 2. UV-visible spectra of riboflavin adsorbed on $\mathrm{Si}: \mathrm{Zr}$ (a) and in solution (b).

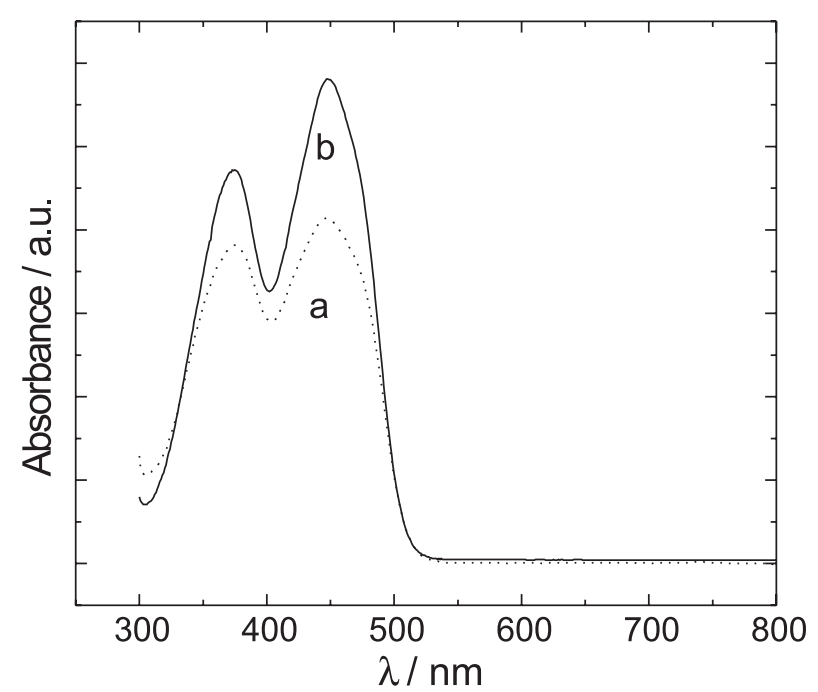

Figure 3. UV-visible spectra of FAD adsorbed on $\mathrm{Si} Z \mathrm{Zr}$ (a) and in solution (b). 
RF verified by the change in the ratio between the absorption bands can be observed. These were not observed with adsorbed FAD and FMN (data not shown for FMN). This information reinforces the proposal that the type of immobilization of FAD and FMN on the $\mathrm{Si}: \mathrm{Zr}$ surface is different from that for RF, and suggests that the interaction between Si:Zr and RF should occur via the isoalloxazine ring.

\section{Electrochemical behavior of the adsorbed flavins}

Cyclic voltammograms (CVs) obtained for the $\mathrm{Si}: \mathrm{Zr}$ modified carbon paste electrode (Figure 4a) did not show any current peak in the potential range investigated, while for the Si:Zr:FAD modified carbon paste (Figure 4b) a clear redox process can be observed indicating that FAD was immobilized on $\mathrm{Si}: \mathrm{Zr}$ presenting a good electrochemical signal. The flavin may accept two electrons from the electrode and two protons from the solution to change into $\mathrm{FADH}_{2}$, as shown in Figure $1 \mathrm{~b}$.

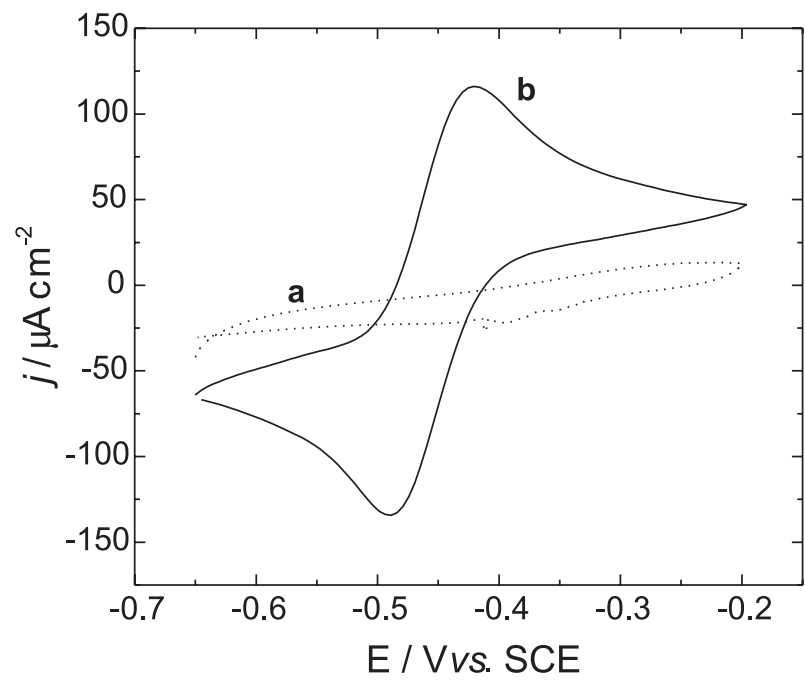

Figure 4. Cyclic voltammograms obtained in $0.1 \mathrm{~mol} \mathrm{~L}^{-1}$ phosphate buffer solution at $\mathrm{pH} 7$ for $\mathrm{Si}: \mathrm{Zr}$ (a) and $\mathrm{Si}: \mathrm{Zr}: F A D$ (b) modified carbon paste electrode at a scan rate of $20 \mathrm{mV} \mathrm{s}^{-1}$.

The electrochemical behavior of adsorbed RF, FMN and FAD presented very similar profiles as can be observed in Figure 5. The formal potential, $E^{\circ}$, determined using the following equation: ${ }^{31} E^{\mathrm{o}}=\left(E_{\mathrm{pc}}+E_{\mathrm{pa}}\right) / 2$, where $E_{\mathrm{pc}}$ is the cathodic and $E_{\mathrm{pa}}$ the anodic peak potential, was about $0.46 \mathrm{~V}$ at $\mathrm{pH} 7$ for all studied flavins. The same potential was observed for flavins in solution. ${ }^{32}$

A linear dependence of the anodic peak current on the square root of scan rates, $v^{1 / 2}$, is illustrated in Figure 6 for the three adsorbed flavins. This behavior suggests a diffusion-controlled redox process. However, as no decrease in peak current after many repeated cycles was observed, indicating that the flavins are strongly adsorbed on the $\mathrm{Si}: \mathrm{Zr}$, the redox process could be controlled by the diffusion of counter ions to keep the electroneutrality on the electrode surface. Other possibilities for this behavior are due to resistance of the material or a mechanism of electron transfer occurring by the electron jumping process. Since, this behavior is observed when in high concentration of the supporting electrolyte the mechanism of electron transfer is more likely to occur.

The separations of the peak potentials, $\Delta E_{\mathrm{p}}\left(\Delta E_{\mathrm{p}}=E_{\mathrm{pa}}\right.$ $\left.E_{\mathrm{pc}}\right)$, were about $55 \mathrm{mV}$ for $\mathrm{Si}: \mathrm{Zr}: R F, 60 \mathrm{mV}$ for $\mathrm{Si}: Z \mathrm{r}: F M N$ and Si:Zr:FAD, almost constant with changes of the scan rate. In addition, the ratios between cathodic and anodic

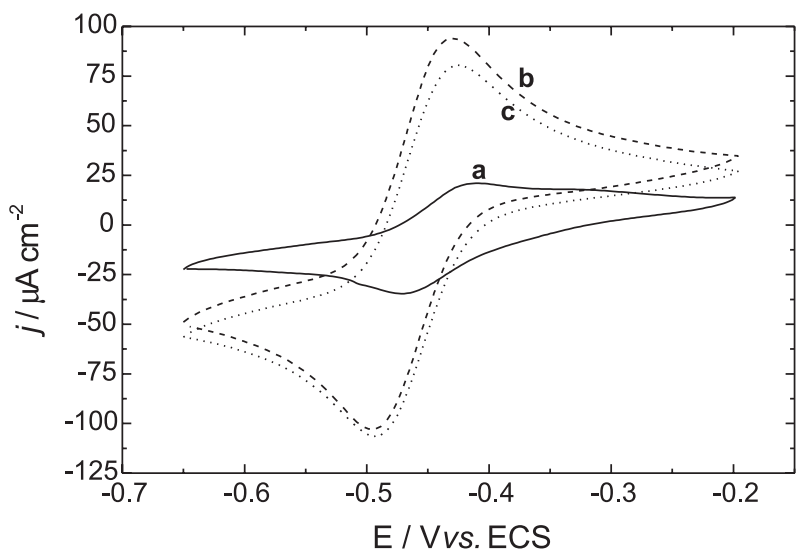

Figure 5. Cyclic voltammograms obtained in $0.1 \mathrm{~mol} \mathrm{~L}^{-1}$ phosphate buffer solution at $\mathrm{pH} 7$ for Si:Zr:RF (a), Si:Zr:FMN (b) and Si:Zr:FAD (c) modified carbon paste electrodes at a scan rate of $20 \mathrm{mV} \mathrm{s}^{-1}$.

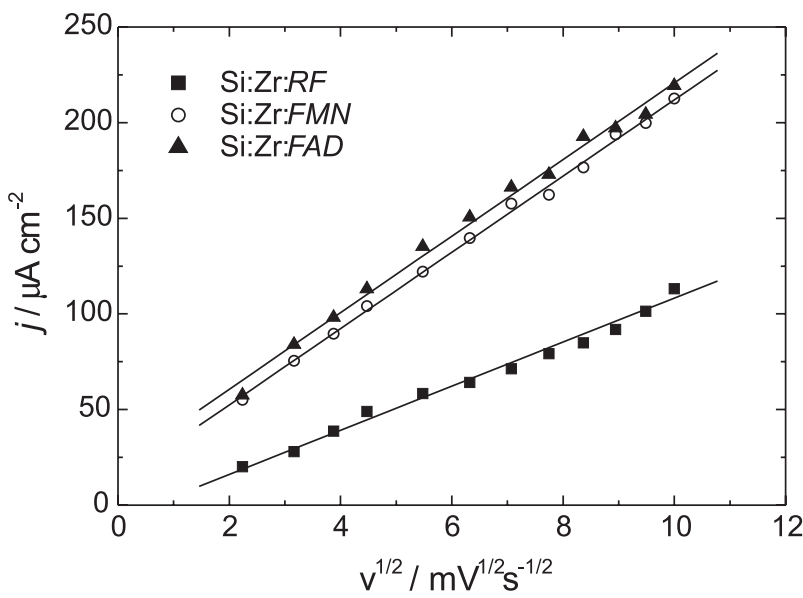

Figure 6. Dependence of the anodic peak current on the square root of the scan rate obtained for Si:Zr:RF, Si:Zr:FMN and Si:Zr:FAD modified carbon paste electrodes in $0.1 \mathrm{~mol} \mathrm{~L}^{-1}$ phosphate buffer, $\mathrm{pH} 7$. 
peaks currents were close to unity. This behavior suggests a good electron transfer rate between the adsorbed flavins and the electrode. ${ }^{33,34}$

The number of electrons transferred between the electrode and the adsorbed flavin during the redox process were calculated using the equation $E_{\text {fwhm }}=90.6 / n$, where $n$ is the number of electrons participating in the reaction and $E_{\text {fwhm }}$ is the peak width at half height..$^{31,33}$ For the three adsorbed flavin on $\mathrm{Si}: \mathrm{Zr}$, the number of electrons was close to 1.5 , which indicates that part of the flavins are going to a semiquinone state during the redox process.

The ions can affect the electrochemical response of the electrode due to an interaction with the adsorbed electroactive species or even with the Si:Zr matrix. Therefore, the influence of different electrolytes on $E^{0^{\prime}}$ and $\Delta E_{\mathrm{p}}$ was investigated and the obtained results are shown in Table 1. For both RF and FAD, the different cations have a small effect on the $E^{\circ}$, except for $\mathrm{Ca}^{2+}$, which leads to a shift in the $E^{\circ}$ toward less negative values, suggesting an interaction between $\mathrm{Ca}^{2+}$ and flavins stabilizing its reduced form. The results shown in the Table 1 were obtained from the average of three measurements. In some cases, such as in solution containing $\mathrm{Li}^{+}$and $\mathrm{ClO}_{4}^{-}$; high

Table 1. Effect of different supporting electrolytes on $E^{0^{\prime}}$ and on $\Delta E_{\mathrm{p}}$ for $\mathrm{Si}: \mathrm{Zr}: R F$ and $\mathrm{Si}: \mathrm{Zr}: F A D$ obtained in $0.1 \mathrm{~mol} \mathrm{~L}^{-1}$ solutions at $\mathrm{pH}^{\mathrm{p}} 7$, scan rate of $20 \mathrm{mV} \mathrm{s}^{-1}$

\begin{tabular}{lccrc}
\hline Cations & \multicolumn{2}{c}{$\mathrm{Si}: \mathrm{Zr}: R F$} & \multicolumn{2}{c}{$\mathrm{Si}: \mathrm{Zr}: F A D$} \\
$0.1 \mathrm{~mol} \mathrm{~L}$ & $\Delta E_{p} / \mathrm{mV}$ & $E^{\alpha^{\prime}} / \mathrm{mV}$ & $\Delta E_{p} / \mathrm{mV}$ & $E^{0^{\prime}} / \mathrm{mV}$ \\
\hline $\mathrm{Li}^{+}$ & $115 \pm 15$ & $-407 \pm 9$ & $102 \pm 14$ & $-412 \pm 2$ \\
$\mathrm{Na}^{+}$ & $102 \pm 2$ & $-405 \pm 4$ & $135 \pm 10$ & $-413 \pm 3$ \\
$\mathrm{~K}^{+}$ & $99 \pm 9$ & $-388 \pm 5$ & $103 \pm 5$ & $-405 \pm 2$ \\
$\mathrm{NH}_{4}^{+}$ & $91 \pm 7$ & $-396 \pm 4$ & $79 \pm 8$ & $-435 \pm 4$ \\
$\mathrm{Ca}^{2+}$ & $97 \pm 10$ & $-376 \pm 7$ & $134 \pm 10$ & $-373 \pm 8$ \\
\hline $\mathrm{Anions}^{2}$ & \multicolumn{2}{c}{$\mathrm{Si}: \mathrm{Zr}: R F$} & \multicolumn{2}{c}{$\mathrm{Si}: \mathrm{Zr}: F A D$} \\
$0.1 \mathrm{~mol} \mathrm{~L}{ }^{-1}$ & $\Delta E_{p} / \mathrm{mV}$ & $E^{\circ} / \mathrm{mV}$ & $\Delta E_{p} / \mathrm{mV}$ & $E^{0^{\prime}} / \mathrm{mV}$ \\
\hline $\mathrm{Cl}^{-}$ & $123 \pm 10$ & $-387 \pm 1$ & $104 \pm 11$ & $-433 \pm 6$ \\
$\mathrm{NO}_{3}^{-}$ & $105 \pm 4$ & $-405 \pm 4$ & $106 \pm 11$ & $-425 \pm 2$ \\
$\mathrm{SO}_{4}^{2-}$ & $104 \pm 9$ & $-421 \pm 6$ & $93 \pm 5$ & $-417 \pm 3$ \\
$\mathrm{ClO}_{4}^{-}$ & $207 \pm 16$ & $-474 \pm 1$ & $135 \pm 12$ & $-414 \pm 5$ \\
\hline & \multicolumn{3}{c}{}
\end{tabular}

uncertainties were verified due to the poor resolution of the peaks in the voltammograms. The $E^{\mathrm{o}^{\prime}}$ values for $\mathrm{Si}: \mathrm{Zr}: F M N$ in different electrolytes are not presented here because the voltamograms were not well defined, showing that the interaction is not exactly the same as in the FAD case.

Table 2 shows the influence of different buffer systems on the redox process of the adsorbed flavins. With the exception of Si:Zr:RF in a TRIS buffer solution, in all the other cases a small $\Delta E_{\mathrm{p}}$ value was observed when compared with electrolytes solution. Presumably, this behavior might be explained with a more efficient electron transfer in buffer solutions. A better-defined voltamogram for three immobilized flavins was obtained in phosphate buffer solution and the ratio of anodic and cathodic peak currents were close to unity. This behavior in phosphate buffer solutions may be related to their interaction with the Si:Zr matrix or even with the flavins, making the electron transfer easier, or due to the buffering effect. For RF immobilized on zirconium phosphate in a phosphate buffer solution, $E^{0^{\prime}}$ shifts towards more negative values were observed, suggesting a competition between phosphate groups of the zirconium phosphate and from the solution. ${ }^{16}$ This influence of phosphate from solution was not observed for RF adsorbed on titanium phosphate ${ }^{18}$ and nor for FAD or FMN adsorbed on $\mathrm{Si}: \mathrm{Zr}$, suggesting that the interaction between FAD/FMN and the Si:Zr, that might occur via the phosphate groups, is not influenced by the phosphate groups from the buffer solution.

Figure 7 shows that the effect of $\mathrm{pH}$ on the $E^{\mathrm{o}^{\prime}}$ of the adsorbed flavins is similar to that observed for these species in solution: the $E^{\mathrm{o}^{\prime}}$ shifts to less negative values when the $\mathrm{pH}$ decreases. The slope was close to $-50 \mathrm{mV}$ per decade of $\mathrm{pH}$ for FMN and FAD, while for adsorbed RF a less pronounced influence of $\mathrm{pH}$ in the range between 4 and 5 is observed, suggesting that the $\mathrm{Si}: \mathrm{Zr}$ matrix causes some protecting effect in this range. This behavior may be related to its immobilization through the isoalloxazine ring. For FAD and FMN, the immobilization might occur via the phosphate groups, leaving the isoalloxazine ring free, and these adsorbed species can exhibit the same behavior as in

Table 2. Buffer effect on $E^{\circ}$ and $\Delta E_{\mathrm{p}}$ for Si:Zr:RF, Si:Zr:FMN and Si:Zr:FAD obtained in $0.1 \mathrm{~mol} \mathrm{~L}^{-1}$ buffer solutions at $\mathrm{pH} 7$, scan rate of $20 \mathrm{mV} \mathrm{s}^{-1}$

\begin{tabular}{|c|c|c|c|c|c|c|}
\hline \multirow{2}{*}{$\begin{array}{l}\text { buffer } 0.1 \mathrm{~mol} \mathrm{~L}^{-1} \\
\text { pH } 7\end{array}$} & \multicolumn{2}{|c|}{$\mathrm{Si}: Z \mathrm{r}: R F$} & \multicolumn{2}{|c|}{$\mathrm{Si}: Z r: F M N$} & \multicolumn{2}{|c|}{$\mathrm{Si}: \mathrm{Zr}: F A D$} \\
\hline & $\Delta E_{p} / \mathrm{mV}$ & $E^{0^{\prime}} / \mathrm{mV}$ & $\Delta E_{p} / \mathrm{mV}$ & $E^{0^{\prime} / \mathrm{mV}}$ & $\Delta E_{p} / \mathrm{mV}$ & $E^{0^{\prime} / \mathrm{mV}}$ \\
\hline PIPES & $50 \pm 7$ & $-456 \pm 10$ & $51 \pm 1$ & $-466 \pm 4$ & $70 \pm 2$ & $-451 \pm 1$ \\
\hline HEPES & $40 \pm 6$ & $-446 \pm 7$ & $58 \pm 6$ & $-457 \pm 13$ & $72 \pm 1$ & $-451 \pm 1$ \\
\hline Phosphate & $53 \pm 3$ & $-443 \pm 2$ & $61 \pm 2$ & $-464 \pm 3$ & $68 \pm 2$ & $-460 \pm 1$ \\
\hline TRIS & $140 \pm 14$ & $-402 \pm 1$ & $58 \pm 1$ & $-459 \pm 1$ & $89 \pm 1$ & $-423 \pm 8$ \\
\hline
\end{tabular}

PIPES = Piperazine-N,N'-bis(2-ethanesulfonic acid); HEPES = N-2-Hydroxyethylpiperazine-N'-2-ethanesulfonic acid; TRIS = Tris (hydroxymethyl) aminomethane. 

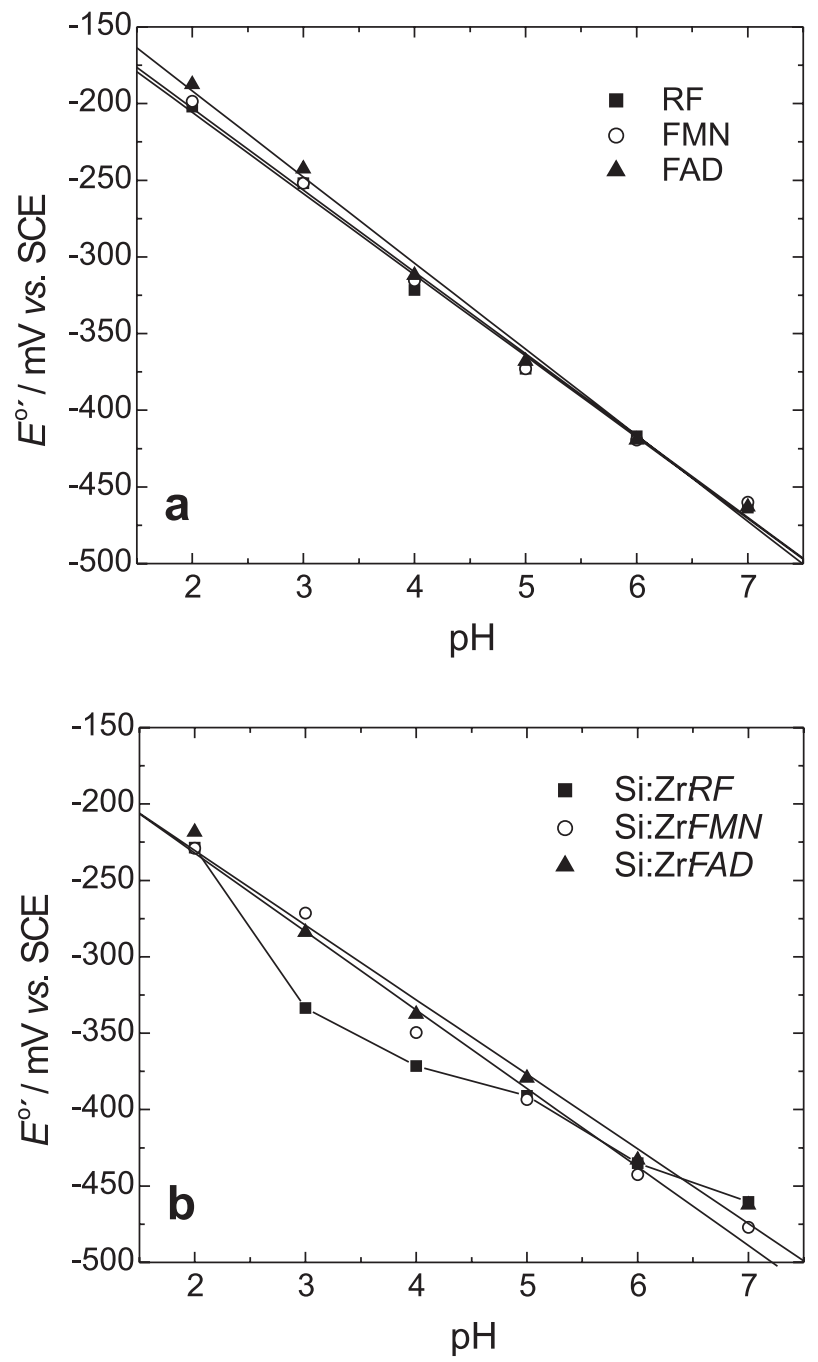

Figure 7. Dependence of the $\mathrm{E}^{\mathrm{o}^{-}}$on the solution $\mathrm{pH}$ for adsorbed flavins (a) and $1.0 \times 10^{-4} \mathrm{~mol} \mathrm{~L}^{-1}$ flavins solution (b), obtained in 0.1 mol L-1 phosphate buffer solution at a scan rate of $20 \mathrm{mV} \mathrm{s}^{-1}$.

solution with respect to the $E^{\mathrm{o}^{\prime}}$ dependence on the solution $\mathrm{pH}$. This is further evidence to support that a different mechanism of adsorption occurs for RF compared to FAD and FMN. Shinohara et al. ${ }^{29}$ reported a weaker adsorption of $\mathrm{RF}$ on the $\mathrm{TiO}_{2}$ surface compared to FAD and FMN, as verified in the present study, and they suggested an important contribution of the phosphate group to the adsorption of flavins. This explanation can be used for $\mathrm{Si}: Z r: F A D$ and $\mathrm{Si}: Z r: F M N$ since the zirconium oxide has a great affinity to the phosphate group. ${ }^{28}$

\section{Conclusions}

The results demonstrated that the Si:Zr material was able to immobilize the RF, FMN and FAD, but with different kinds of interaction, as reveled by the UV-visible spectra and electrochemical behavior of these adsorbed compounds. The immobilization on Si:Zr did not provoke shifting of the formal potential of flavins, even for different $\mathrm{pH}$, suggesting that the behavior of these adsorbed species is similar to that in solution. An exception was in the case of $\mathrm{Si}: \mathrm{Zr}: R F$, where the invariance of the formal potential with the $\mathrm{pH}$ in the range between 4 and 5 was observed.

The FAD and FMN immobilization probably involves the phosphate group interaction present in the flavin structure, but some differences of affinity must be involved since different electrolytes affect the redox process in different ways. For RF, the isoalloxazine ring interaction is thought to occur.

\section{Acknowledgements}

The authors acknowledge FAPESP (State of São Paulo Research Foundation) for financial support.

\section{References}

1. Bruice, T. C.; Acc. Chem. Res. 1980, 13, 256.

2. Bruice, T. C. In Flavins and Flavoproteins; Bray, R. C.; Engel, P. C.; Mayhew, S. E., eds.; Walter De Gruyter and Co.: New York, 1984, p 45.

3. Massey, V.; FASEB, J. 1995, 9, 473.

4. Schmidt, H.-L.; Schuhmann, W.; Biosens. Bioelectron. 1996, $11,127$.

5. Bartlett, P. N.; Tebbutt, P.; Whitaker, R. G.; Prog. React. Kinet. 1991, 16, 56.

6. Hemmerich, P.; Veeger C.; Wood, H. C. S.; Angew. Chem. Int. Edit. 1965, 4, 671.

7. Birss, V. I.; Guha-Thakurta, S.; McGarvey, C. E.; Quach, S.; Vanýsek, P.; J. Electroanal. Chem. 1997, 423, 13.

8. Narasimhan, K.; Wingard, L. B.; J. Mol.Catal. 1986, 34, 263.

9. Malinauskas, A.; Bioelectrochem. Bioenerg. 1999, 49, 21.

10. Friedman, R. M.; J. Electroanal. Chem. 1999, 472, 147.

11. Cosnier, S.; Fontecave, M.; Limosin, D.; Nivière, V.; Anal. Chem. 1997, 69, 3095.

12. Bergel, A.; Comtat, M.; J. Electroanal. Chem. 1991, 302, 219.

13. Massey, V.; Hemmerich, P.; Biochemistry 1978, 17, 664.

14. Dixon, M.; Biochim. Biophys. Acta 1971, 226, 269.

15. Maedayorita, K.; Russell, G. C.; Guest J. R.; Massey, V.; Williams, C. H.; Biochemistry 1991, 30, 11788.

16. Kubota, L. T.; Gorton, L.; Electroanalysis 1999, 11, 719.

17. Kubota, L. T.; Gorton, L.; J. Solid State Electrochem. 1999, 3,370 .

18. Kubota, L. T.; Munteanu, F.; Roddick-Lanzilotta, A.; McQuillan, A. J.; Gorton, L.; Quim. Anal. 2000, 19, 15.

19. Gorton, L.; Johansson, G.; J. Electroanal. Chem. 1980, 113, 151. 
20. Durfor, C.; Yenser B. A.; Bowers, M. L.; J. Electroanal. Chem. 1988, 244, 287.

21. Edwards, T. R. G.; Cunnane, V. J.; Parsons, R.; Gani, D.; J. Chem. Soc., Chem. Commun. 1989, 1041.

22. Ueyama, S.; Isoda, S.; Maeda, M.; J. Electroanal. Chem. 1989, 264, 149.

23. Kubota, L. T.; Gorton, L.; Roddick-Lanzilotta, A.; McQuillan, A. J.; Bioelectrochem. Bioenerg. 1998, 47, 39.

24. Zaitsena, G.; Gushikem, Y.; Ribeiro, E. S.; Rosatto, S. S.; Electrochim. Acta 2002, 47, 1469.

25. Schiavo, D. A.; Perez, E. F.; Kubota, L. T.; Quim. Nova 2000, 23,832 .

26. Gushikem, Y.; Rosatto, S. S.; J. Braz. Chem. Soc. 2001, 6, 695.

27. Andreotti, E. I. S.; Gushikem, Y.; Kubota, L. T.; J. Braz. Chem. Soc. 1992, 3, 21.
28. Veselý, V.; Pekárek, V.; Talanta 1972, 19, 219.

29. Shinohara, H.; Grätzel, M.; Vlachopoulos, N.; Aizawa, M.; Bioelectrochem. Bioenerg. 1991, 26, 307.

30. Spetnagel, W. J.; Klotz, I. M.; Biopolymers 1978, 17, 1657.

31. Murray, R. W. In Electroanalytical Chemistry; Bard A. J., ed. Dekker: New York, 1984, p 191.

32. Kzenzhek, O. S.; Petrova, S. A.; Bioelectrochem. Bioenerg. 1983, 11, 105.

33. Laviron, E. In Electroanalytical Chemistry; Bard A. J., ed. Dekker: New York, 1982, p 53.

34. Honeychurch, M. J.; Rechnitz, G. A.; Electroanalysis 1998 , $19,453$.

Received: February 8, 2002

Published on the web: September 16, 2002

FAPESP helped in meeting the publication costs of this article. 